\title{
CONSIDERAT,II PRIVIND MEDIUL DE SECURITATE ÎN EUROPA DE EST
}

\author{
ENVIRONMENTAL SECURITY CONSIDERATIONS \\ IN EASTERN EUROPE
}

Col.drd. Viliam PASTOR*

\begin{abstract}
În ultimii ani, amenințări tot mai complexe au apărut la adresa securităţii, ceea ce scoate în evidență nevoia unei cooperări tot mai puternice și mai strânse în materie de securitate la toate nivelurile. Criza provocată de virusul SARS-CoV-2 a adus în prim-plan securitatea în Europa, testând atât reziliența dată de infrastructura critică, cât și pregătirea pentru situațiile de criză și mijloacele de gestionare a acestora. Europa de Est, măcinată de conflicte în ultimele decenii, se confruntă și astăzi cu numeroase provocări, cum ar fi creșterea populației, scăderea nivelului de trai și schimbările climatice datorate încălzirii globale. Acestea din urmă vor exacerba situația în viitor. Deoarece securitatea mediului este o preocupare emergentă care nu poate fi abordată cu soluții tradiționale, trebuie dezvoltate noi modalități de a face față acesteia. Cooperarea formează nucleul unor astfel de mijloace, vizând o abordare intersectorială și garantând o participare largă a părților interesate în vederea integrării principiului dezvoltării durabile în politicile naționale.
\end{abstract}

In recent years, more and more complex threats to security have emerged, highlighting the need for stronger and closer security cooperation at all levels. The crisis caused by SARS CoV-2 virus brought to the forefront security in Europe, testing both the resilience once the infrastructure of critical complicated, and preparation for crisis situations and the means for managing them. Eastern Europe, plagued by various conflicts in recent decades, still faces many challenges today, such as uncontrolled population growth, declining living standards and climate change due to global warming. The latter will exacerbate the situation in the future. As environmental security is an emerging concern that cannot be addressed with traditional solutions, new ways of dealing with it need to be developed. Cooperation forms the core of such means, aiming an intersectoral approach and ensuring broad stakeholder participation in order to integrate the principle of sustainable development into national policies.

Cuvinte-cheie: securitate; putere militară; cooperare.

Keywords: security; military power; cooperation.

„Să asiguri pacea înseamnă să te pregăteşti de război”.

Carl von Clausewitz

De la începutul agresiunii rusești împotriva Ucrainei în 2014, situația geopolitică și de securitate în Europa de Est și în Europa în ansamblu s-a schimbat. De mai bine de șapte ani, nu s-a îmbunătăţit și chiar a avut tendința de agravare treptată, care a fost dovedită în timpul exercițiilor militare ruso-belaruse „Vest-2017”, respectiv prin prezența unor forțe militare însemnate ruse la granița cu Ucraina în anul 2021. Un vid de securitate a apărut după prăbușirea sistemului de securitate colectivă în Europa de Est, în ciuda eforturilor continue ale Organizaţiei pentru Securitate și

\footnotetext{
*Universitatea Națională de Apărare „Carol I” e-mail:vili_pastor@yahoo.com
}

Cooperare în Europa (OSCE), Uniunii Europene (UE), Organizației Tratatului Atlanticului de Nord (NATO) și chiar Organizației Naţiunilor Unite (ONU). În mod corespunzător, s-a estimat faptul că principala cauză a deteriorării situației de securitate din regiune a fost politica agresivă a Rusiei, corelată cu slăbiciunea arătată de principalele organizații internaționale - Organizația Națiunilor Unite (ONU), Organizaţia pentru Securitate și Cooperare în Europa (OSCE) și Consiliul Europei $(\mathrm{CoE})$. NATO ar trebui să joace un rol cheie în securitatea regională în Europa de Est în formele de extindere a NATO către Est, consolidând rolul NATO în regiune și/sau dezvoltarea parteneriatului special cu NATO. De asemenea, UE ar trebui să joace un rol activ de securitate prin consolidarea 
sancțiunilor împotriva Rusiei, scăderea dependenței de resursele energetice rusești, asistență pentru țările din regiune în consolidarea rezistenței lor naționale și gestionarea provocărilor de securitate. Apare, astfel, ideea stabilirii unui nou format de securitate regională, dar fără Rusia, sub umbrela UE/NATO. În timp ce răspundeau la întrebarea care este locul și rolul Ucrainei în sistemul de securitate din Europa de Est, aproape toți experții în domeniu au considerat Ucraina un furnizor de securitate pentru Europa de Est, o componentă cheie și un actor principal al securitătii europene, un nou pilon est-european al securitățiitransatlantice, unavanpost estic împotriva noilor provocări și amenințări, cu un rol cheie în descurajarea politicii agresive rusești şi în demonstrarea unei alternative la modelul de dezvoltare al Rusiei pentru alte state din zona postsovietică. Ucraina devine un exemplu și o sursă de experiență în combaterea tuturor tipurilor de război hibrid. Astfel, soluționarea conflictului rusoucrainean ar contribui la consolidarea securității regionale în Europa de Est.

Rezultatul oricărui efort de a crea o nouă arhitectură de securitate este, prin urmare, desigur, incert, dar ar trebui încercat, totuşi. Liderii occidentali ar trebui să urmeze această cale cu încredere și fără scuze. Dacă Rusia nu va dori să negocieze un acord privind consolidarea securității regionale în Europa de Est, atunci vor fi luate în considerare anumite opțiuni pentru o înăsprire a politicii viitoare împotriva Rusiei ${ }^{1}$. Într-adevăr, o serie de astfel de răspunsuri ar trebui dezvoltate în prealabil, inclusiv posibilitatea accelerării luării în considerare a aderării la NATO, pentru statele neutre, care sunt, ulterior, constrânse sau atacate de Rusia. De preferat, desigur, ar fi să se evite acest lucru. Situația strategică actuală, care implică majoritatea marilor economii ale lumii și mai multe dintre statele din Europa care dețin arme nucleare, este destul de periculoasă și nu va deveni mai puțin periculoasă, dacă este lăsată pur și simplu pe pilot automat.

\section{Interesele și obiectivele UE în țările est-europene}

Interesul de bază al UE pentru zona sa estică este de a fi înconjurat de un ,,inel de prieteni”, aşa după cum afirma președintele Comisiei Europene în $2002^{2}$. În anul următor, când și-a lansat politica de vecinătate, UE a anunțat că soluționarea conflictelor este una dintre prioritățile sale cheie. De atunci, a existat o creștere semnificativă a conflictului în vecinătatea blocului sovietic, dar nu a existat o creștere paralelă a nivelului de ambiție al statelor membre, de a aborda această zonă sensibilă. Pentru UE, tranziţia țărilor postsovietice de la comunism la democrație competitivă, administrațiile legate de statul de drept și economiile de piață funcționale nu numai că vor spori pacea și stabilitatea, ci vor promova și creșterea economică, dezvoltarea durabilă, legăturile intersocietale și culturale și relații puternice durabile în vecinătatea sa.

În timp ce sprijinul UE pentru această transformare a produs rezultate mixte, blocul sovietic trebuie să recunoască faptul că un eșec total al procesului în vecinătatea sa de est este posibil și ar avea consecințe grave. Belarusul poate servi ca un exemplu negativ a ceea ce se poate întâmpla atunci când o transformare politică și economică eșuează. Acum, când Lukashenko se apropie de bătrânețe și se confruntă cu un declin rapid al legitimității sale, din cauza suprimării protestelor opoziţiei, există întrebări legate de problemele succesiunii, de suveranitatea bielorusă în statul Uniunii și de durabilitatea modelului economic al țării. În cel mai bun caz, Belarusul va rămâne o țară slabă și săracă la graniţa UE. În cel mai rău caz, va deveni un stat client cobeligerant, pe care Rusia îl folosește pentru a amenința și a contesta în mod direct suveranitatea și integritatea teritorială a UE. Ucraina, Moldova și Georgia ar putea forma o zonă de instabilitate, dominată de Moscova - din care Kremlinul ar putea organiza o subversiune clandestină și operațiuni militare convenționale. Fără o izolare teritorială comparabilă cu cea oferită de Marea Mediterană, aceasta ar reprezenta o amenințare mai puternică pentru statele est-europene.

$\mathrm{O}$ astfel de frământare contrazice argumentele în favoarea „stabilităţii autoritare”. Chiar și în regiunile separatiste controlate îndeaproape de serviciile de informații rusești, autoritățile locale sunt deseori provocate și, uneori, lovite de revolte publice. În Osetia de Sud, protestele împotriva alegerilor, disputate din 2012, s-au încheiat cu moartea candidatului opoziţiei (care ar fi putut câștiga acel vot). În Abhazia, ,președintele” ales a fost destituit de două ori - în 2014 și, respectiv, în 2020 - de revolte populare, provocate de alegeri presupus trucate. Chiar dacă UE ar pune capăt sprijinului pentru transformarea politică 
și economică din vecinătatea sa estică, dorința populară pentru un guvern responsabil nu ar dispărea și nici instabilitatea, creată de procesele politice eșuate.

Principalul obiectiv al UE în zona sa estică este de a crea „spaţiul comun al democrației comune, prosperității și stabilității”’3, la care a făcut referire recent Consiliul European. Pentru unii lideri europeni, transformarea politică este încă o condiţie prealabilă a eforturilor de realizare a altor obiective. Eforturile de combatere a corupției, a criminalității organizate și a spălării banilor atât în UE, cât și în vecinătatea sa estică au câștigat o oarecare atenție din partea mass-mediei, în urma Raportului Mueller şi a scandalului din jurul deciziei președintelui Donald Trump, din 2019, de a demite ambasadorul SUA din Ucraina. În cele din urmă, integritatea și profesionalismul autorităților locale de anchetă și justiție vor fi un factor cheie în privința posibilității UE de a-și atinge obiectivele în estul Europei.

Obiectivele UE în estul Europei acoperă, de asemenea, aspecte precum mobilitatea forței de muncă și migrația, infrastructura, tinerii, educaţia, grupurile minoritare etnice, digitalizarea, pașii către alinierea economică, asistența medicală, în special în legătură cu Covid-19, și egalitatea de sex. Totuși, acestea sunt portofolii birocratice destul de apolitice, care arată puține lucruri legate de capacitatea Europei de a-și implementa politica externă. Acest lucru se datorează, parțial, faptului că Belarusul și Azerbaidjanul respectă, în general, diferite norme politice față de UE, dar fac parte, în mod formal, din vecinătatea sa estică.

În ceea ce privește eforturile UE de a obține o influență politică asupra deciziilor din zona esteuropeană, legăturile energetice cu Rusia sunt singura problemă importantă din punct de vedere strategic, acoperită de acordurile dintre părți. $\mathrm{Cu}$ toate acestea, tranzitul energetic este un domeniu pe care Moscova îl folosește pentru a exercita presiuni asupra statelor din estul Europei. $\mathrm{Cu}$ alte cuvinte, se pune problema dacă UE poate și ar trebui să sprijine statele est-europene în tranziția lor către democratie liberală, o societate deschisă, statul de drept și piețe libere, sau dacă acestea ar trebui să mențină legături strânse cu Moscova.

Sprijinul UE pentru tranzițiile politice și economice din zona estică nu a fost niciodată necontestat. Rusia consideră instabilitatea, vulnerabilitatea, slăbiciunea și dependența acestor țări ca un mecanism cheie prin care să-și exercite influența în vecinătatea sa imediată. Rusia a folosit dependențele economice-în special cele referitoare la petrol și gaze naturale - pentru a avea controlul asupra Georgiei, Ucrainei și Belarusului. Moscova a folosit, de asemenea, corupția țintită, războiul informațional, fraudarea alegerilor și operațiunile de informații pentru a discredita, a extorca sau a intimida actorii politici, cu scopul de a asigura puterea persoanelor pe care le crede că vor proteja interesele rusești. De parcă asta nu ar fi fost suficient în sine, Moscova a folosit și forța militară pentru a obține anumite avantaje. Inutil să spunem că reformele legate de statul de drept, piețele libere și sistemul politic pe care UE îl prevede pentru vecinătatea sa ar reduce vulnerabilitatea țărilor din estul Europei (Parteneriatul estic) la presiunea Rusiei.

Tacticile Rusiei, combinate cu lipsa initiativelor constructive din regiune, $\mathrm{i}$-au adus o reputație de „deflector strategic" este deosebit de potrivită în ceea ce privește operațiunile sub acoperire, care construiesc rețele clandestine într-o țară, pentru a-i slăbi structurile instituționale, politice, economice și de securitate. Scopul final al acestor operațiuni este de a face țara să cedeze presiunilor străine sau, dacă nu o face, să declanșeze un conflict ,intern”, care oferă un pretext pentru o interventie.

Ucraina oferă multe exemple despre modul în care Rusia aplică aceste tactici. Evenimentele din timpul președintelui Viktor Ianukovici au arătat că Kremlinul are posibilități ample de a folosi oameni puternici locali, oligarhi și personalități publice, dornice să-l ajute să își atingă obiectivele. Centralizarea puterii, captarea statului, corupția sistemică și atacurile la adresa independenței presei şi justiţiei sunt atractive pentru elitele locale și pentru oamenii puternici, care încearcă să monopolizeze puterea. În timp ce există o graniță estompată între slăbiciunea internă și vulnerabilitatea indusă de străinătate, o mare parte din succesul operațiunilor sub acoperire se bazează pe exploatarea diviziilor preexistente dintr-o țară. În termeni practici, această graniță nu contează pentru elaborarea politicilor UE, aceasta trebuie să atenueze punctele slabe instituţionale ale parteneriatului estic, indiferent de originea lor.

UE a încercat, uneori, să negocieze aranjamente tranzitorii care să transforme concurența cu Rusia 
într-o situație reciproc avantajoasă. A făcut acest lucru prin implicarea directă cu Rusia, oferind concesii economice și societale și asistență pentru reformă și modernizare. S-a încercat, de asemenea, să se negocieze acorduri de pace pentru conflicte teritoriale prelungite, oferind Rusiei o poziţie de comanagement în instituțiile de securitate comune, așa după cum este stipulat în Memorandumul Meseberg din 2010. Cu toate acestea, atunci când au încercat să pună în aplicare astfel de iniţiative, Rusia și UE nu au reușit să creeze o viziune comună pentru regiune. Acest lucru se datorează diferențelor lor ideologice profunde cu privire la ordinea europeană de securitate. În loc să încurajeze cooperarea, aceste eforturi eșuate au sporit suspiciunea reciprocă.

\section{Mediul de securitate în estul Europei}

Pentru a aborda operațiunile clandestine ale Rusiei în țările est-europene, este nevoie de o politică de contrasubversiune care să le poată proteja reformele economice, financiare, societale și politice. Acest lucru necesită nu numai o poziție mai activă și mai coerentă cu privire la politica existentă, ci și o extindere a influenței în cinci domenii cheie:

- media și activităţi informaționale;

- securitate cibernetică;

- securitate și informații;

- apărare;

- energie.

In primul domeniu, eforturile europene din trecut s-au concentrat pe sprijinirea jurnaliștilor de investigație în cercetarea faptelor. Acest sprijin a venit pe o bază bilaterală sau printr-o coaliție de țări cu aceleași păreri, așa după cum se vede în iniţiative, precum Fondul Visegrad. Cu toate acestea, oricât de importante au fost aceste măsuri, ele nu au reușit să atingă efectele prevăzute. Acest lucru se datorează faptului că, conținutul pe care il produc (dintre care cea mai mare parte este disponibil online) ajunge doar la un public restrâns. Deoarece televiziunea convențională este încă una dintre cele mai importante surse de informații pentru cetățenii țărilor est-europene, este important ca acestea să se adreseze direct respectivului mediu. Stabilirea posturilor de televiziune publice care sunt independente din punct de vedere editorial și financiar de guvern prin taxe de difuzare este doar primul pas în acest proces. De asemenea, este nevoie de un sprijin mai larg sub formă de sfaturi, expertiză, conținutul programului și mecanismele de control al calității.

Extinderea conținutului TV trebuie să țină seama de diversitatea societății. Un model care a fost deosebit de evident în Georgia și Moldova a fost dezinformarea rusă la TV, care vizează minoritățile etnice și lingvistice. Fără capacitatea de a furniza servicii de verificare a faptelor în limbile native ale telespectatorilor, statul a abandonat de facto aceste bule de informații. În țările occidentale, instituțiile publice de radiodifuziune sunt responsabile de furnizarea de informații exacte și accesibile grupurilor minoritare etnolingvistice. Din motive strategice, aceste instituții ar trebui să facă același lucru și în țările est-europene.

În timp ce serviciile publice imparțiale de acest gen ar oferi un conţinut mai precis decât posturile de televiziune deținute de oligarhi sau canalele de propagandă străine, acestea nu ar face ca sursele de dezinformare să dispară. $\mathrm{Cu}$ toate acestea, modificările cadrului de reglementare ar putea face mult mai dificilă răspândirea dezinformării, folosind modelele de afaceri actuale ale acestor puncte de vânzare. În primul rând, normele privind transparența dreptului de proprietate asupra mass-mediei, achiziţionarea mijloacelor de informare în masă, publicitate și finanţare ar face mai dificilă posibilitatea ca puterile străine sau oligarhii să achiziționeze în secret aceste active. În al doilea rând, normele privind autosuficiența financiară a întreprinderilor media ar interzice oligarhilor să finanțeze agențiile de știri pentru a manipula dezbaterea publică. Vor obliga întreprinderile media să trăiască din propriile venituri, fie prin abonamente, fie prin reclame de la terți. Este puțin probabil ca statele est-europene să adopte o astfel de legislație de la sine, deoarece propaganda TV este o sursă importantă de putere și legitimitate a partidelor de guvernământ. Doar presiunea și condiționalităţile pot schimba acest lucru.

În Ucraina, mai multe state membre ale UE susțin o varietate de organizaţii neguvernamentale locale care au dezvoltat o expertiză considerabilă în identificarea și urmărirea dezinformării rusești și locale. $\mathrm{Cu}$ toate acestea, UE nu are structurile necesare pentru a absorbi informațiile generate de partenerii săi locali, pentru a-și adapta strategia de comunicare în consecință și, cel mai important, pentru a ajuta actorii locali să își îmbunătățească 
rețeaua comunicărilor strategice pentru a proteja procesul politic de interferențe. Deși există actori locali capabili în Ucraina, cu care UE poate lucra în domeniul securității informațiilor, există puțini astfel de actori în alte țări din zona est-europeană, așa cum este evident mai ales în Georgia și Moldova. UE trebuie să lanseze programe de consolidare a capacităților în acest sector.

În paralel, operațiunile cibernetice sunt o parte esențială a războiului sub acoperire din secolul XXI. Acest lucru poate fi văzut în eforturi destabilizatoare care implică totul, de la utilizarea datelor în evaluarea stării de spirit și a prejudecăților cetățenilor (și astfel exploatarea acestora prin operațiuni de informare) până la spionaj, la sabotarea misiunilor care paralizează ramurile guvernului sau infrastructura strategică. Îmbunătățirea securității cibernetice și a rezilienței cibernetice în țările est-europene este necesară pentru a contracara acțiunile subversive.

UE a făcut încet progrese în acest domeniu. Totuşi, aceasta nu oferă asistență tehnică pentru a ajuta țările estice să pună în aplicare sistemul lor de apărare cibernetică.

Pentru a-și îmbunătăți capacitatea cibernetică națională, statele est-europene trebuie să încheie parteneriate cu firme IT locale. Dar, în acest sens, sunt puține astfel de companii la care se pot adresa guvernele, cu excepția Ucrainei, care are un sector IT semnificativ și în creștere rapidă. (Moldova a adoptat o legislație pentru a facilita creșterea sectorului în 2019, dar rămâne de văzut dacă acest lucru este sustenabil sub noul guvern al țării.) Prin urmare, țările din estul Europei sunt dependente de companiile și serviciile IT din SUA, Europa, Rusia și China. Iar utilizarea firmelor rusești și chineze ridică îngrijorări deosebit de acute cu privire la securitatea cibernetică.

Multe dintre măsurile pe care trebuie să le ia țările est-europene se referă mai întâi la securitatea cibernetică internă și la suveranitatea cibernetică. Acestea ar trebui să creeze cadrul legal și structurile administrative pentru a certifica programele software și hardware; instituțiile să coordoneze rapid echipele naționale CERT printr-un „super CERT” la nivelul întregii țări și să creeze organisme de criminalistică și anchetă cibernetice. Aceste structuri ar putea audita autorităţile și legislația în materie de securitate cibernetică, ar putea elabora unele repere și obiective clare pentru reformele organizaţionale, ar putea să se angajeze în programe de consolidare a capacităţilor, să furnizeze informații critice privind amenințările cibernetice emergente și iminente și să facă legătura cu autoritățile locale certificate. De asemenea, ar putea ajuta la adoptarea standardelor UE pentru implementarea infrastructurii 5G în aceste țări. Este dincolo de capacitatea statelor est-europene de a efectua o evaluare tehnică completă a lanțurilor de aprovizionare complexe - rețele nu numai pentru $5 \mathrm{G}$, ci și, inter-alia, pentru guvern, militare și comunicații de informații. În consecință, au nevoie de ajutor din partea părţilor interesate externe, cum ar fi instituţiile comune de cercetare în domeniul securității cibernetice ale UE.

Structurile funcționale de securitate cibernetică au, de asemenea, un rol important de jucat în combaterea spălării banilor. Legăturile dintre băncile naționale și unitățile de informații cibernetice s-au dovedit importante pentru descoperirea infracțiunilor financiare. Operațiunile de influență străină depind adesea de aceleași canale financiare opace și ilegale pentru a furniza bani necesari acoperirii costurilor operaționale: surse de plată; indivizi corupți; finanţarea organizațiilor frontale (cum ar fi organizaţii neguvernamentale și mass-media) și achiziţionarea de facilități de depozitare, armament și alte active pentru a pregăti insurgențele armate. Tipurile de operațiuni ascunse descrise mai sus sunt afaceri costisitoare. Întreruperea rețelelor de sprijin financiar ar fi o modalitate eficientă de combatere a acestora. În cele din urmă, autoritățile de securitate cibernetică și organismele de supraveghere financiară vor împiedica operațiunile secrete străine doar în cazul în care agențiile locale de aplicare a legii arestează vinovații, le confiscă bunurile și închid organizațiile de acoperire ilicite.

Toate statele est-europene suferă de conflicte de interese între competențele agențiilor lor de anchetă și de aplicare a legii, salarii mici în sectorul public (care sporesc vulnerabilitatea instituțiilor la coruptie), legi procedurale opace, proceduri de investigație complicate-birocratice, coduri penale pline de lacune și contradicții, cooperare instituțională slabă sau absentă între organele de aplicare a legii, structuri ierarhice, centralizate, în care câțiva factori de decizie de rang înalt pot bloca sau împiedica investigațiile în întreaga ramură a serviciilor și un control politic semnificativ 
asupra organismelor de anchetă. Au existat puține reforme profunde ale agențiilor de investigare și de aplicare a legii în țările est-europene, iar acolo unde au avut loc astfel de reforme (așa cum s-a făcut, sub ministrul de interne Vano Merabishvili, în Georgia, sau de către procurorul general Ruslan Ryaboshapka în Ucraina), acestea au fost supuse unor campanii intense de obstrucție și defăimare de elitele din afacerile locale și de forțele politice stabilite. Fără o presiune intensă din străinătate, nici măcar reformele minore nu ar fi avut loc.

Într-un mediu contestat, cum sunt țările din estul Europei, sectoarele de informații și securitate sunt esențiale. Fără informații de încredere și eficiente, statele estice nu au nicio șansă să reziste operațiunilor destabilizatoare ale Rusiei. Prin monitorizarea constantă a situației amenințărilor, agențiile de informații joacă un rol central atât în informarea factorilor de decizie cu privire la operațiunile ostile, cât și în renunțarea la serviciile de aplicare a legii și de securitate financiară pentru investigarea și urmărirea penală a persoanelor și rețelelor vinovate. Problema este că serviciile de informații interne ale țărilor est-europene sunt fie nesigure, deoarece fac efectiv parte din sistemul politic (făcându-le vulnerabile la corupție şi abuzuri pentru câștiguri politice și economice), fie au doar capacități și capabilități slab dezvoltate.

Prin urmare, UE trebuie să sprijine urgent reforma și să elaboreze programe de consolidare a capacităților, pentru țările din est, în aceste domenii. UE ar trebui să ofere programe de consolidare a capacităţilor, coordonare structurală în ceea ce privește amenințările, asistență tehnică (în special în domeniul informațiilor transfrontaliere cu semnale) și informații militare - în schimbul unei reforme aprofundate a serviciilor de informaţii și securitate. $O$ astfel de reformă ar presupune o responsabilitate democratică sporită, o reducere a suprapunerii dintre competențele și procedurile agențiilor de aplicare a legii și dispoziţii menite să reducă corupția. În Ucraina, European Union Advisory Mission (EUAM) s-a dovedit de neprețuit în legătura cu serviciile locale în privința nevoilor acestora, precum și în evaluarea progresului (și, din păcate, a regresiei) reformei serviciilor de informații. Pe baza experienței EUAM, UE ar putea înființa birouri de legătură ale serviciilor de informații din Tbilisi și Chișinău. Ar trebui să creeze o celulă de sprijin și coordonare a informațiilor din vecinătatea estică la Bruxelles, pentru a coordona asistența (aşa cum face grupul de sprijin) și pentru a facilita schimburile practice de informații. UE ar putea extinde Şcoala comună de informații a UE, un proiect PESCO pentru copii, dincolo de cooperarea restrânsă dintre statele mediteraneene de est - astfel încât să acopere țările din estul Europei în care Rusia are interese strategice. Școala ar fi atunci adecvată pentru instruirea personalului de informații din țările est-europene.

În plus, UE trebuie să își mărească dramatic propriile capacităţi de informații în vecinătatea sa estică. Acolo unde este necesar, agențiile de informații ale statelor membre ale UE ar trebui să compenseze neajunsurile din serviciile de informații interne ale țărilor estice și în special serviciile de contraspionaj.

Acest lucru este deosebit de important în situaţiile de schimbare revoluţionară în care apar noi structuri administrative și de altă natură - ceva care reprezintă încă o posibilitate distinctă în toate țările est-europene. Aceste situații oferă Rusiei posibilitatea de a-și folosi rețelele de organizații frontale pentru a-și plasa aliații în noi structuri și pentru a împiedica eforturile de reformă din interior. UE a fost prea reactivă în aceste scenarii, lăsând-o în imposibilitatea de a monitoriza în mod eficient dezvoltarea situaţiei şi persoanele care conduc schimbarea. Desigur, există întotdeauna o șansă semnificativă de a greși într-un mediu turbulent. Dar imposibilitatea UE de a dispune de informații adecvate împiedică succesul. În trecut, țările est-europene au compensat adesea acest lucru, bazându-se pe informațiile americane.

Moscova vede operațiunile sub acoperire ca fiind principala modalitate de a destabiliza guvernele și de a-și extinde influența. $\mathrm{Cu}$ toate acestea, le perturbă și în moduri mai deschise. Chiar și fără a invada alte țări, Rusia folosește, uneori, o demonstrație militară de forță la granița țărilor vecine pentru a sublinia dominanţa escaladării sale, influenţându-le astfel deciziile.

Unii diplomați europeni cred că transformarea țărilor est-europene în state nealiniate sau neutre ar contribui la stabilizarea regiunii. Totuși, acest lucru nu s-ar întâmpla automat și este puțin probabil ca Moscova să respecte o astfel de nealiniere. Întradevăr, nealinierea ar fi o opțiune viabilă pentru țările estice numai dacă şi-ar consolida capacitatea de a se apăra de subversiunea externă. 
Există o nevoie urgentă de a reduce vulnerabilitatea țărilor est-europene în fața amenințării forțelor, precum cele din Moldova și cea a armatei ruse din Georgia și Ucraina. Desigur, este dificil să ne imaginăm o situație în care statele estice ar fi imune la atacurile militare ale unei mari puteri regionale care deține armament nuclear, precum Rusia. La fel ca multe state nealiniate din timpul Războiului Rece, acestea ar trebui să facă pregătiri militare, menite să convingă potențialii agresori că agresiunea militară ar avea un cost prea mare. Ucraina a arătat valoarea acestei abordări în 2015 și 2016. Rusia a menţinut teoretic dominarea escaladării în Ucraina, dar orice escaladare ulterioară ar fi necesitat un efort rus mult mai mare, unul pentru care Kremlinul ar fi avut nevoie de justificare faţă de propriul popor. Cu toate acestea, cazul Ucraina a arătat, de asemenea, că problema creșterii eficacităţii forțelor armate ale unei țări nu se referă doar la echipamente, ci și la un angajament cuprinzător, pe termen lung, în sprijin militar și de apărare.

Asistența în planificarea cuprinzătoare a apărării este necesară în special pentru Georgia și Moldova. Deoarece Moldova nu se învecinează direct cu Rusia, și forțele separatiste din Transnistria prezintă o amenințare diferită pentru unităţile militare rusești convenționale, armata moldovenească trebuie să se transforme într-o forță mobilă de înaltă pregătire, care să se coordoneze bine cu poliția pentru a contracara rapid amenințările hibride. În schimb, Georgia este deosebit de vulnerabilă, din cauza poziției sale geografice, cu forțe militare ruse considerabile desfășurate pe teritoriul său și peste graniță. Politica de apărare a Georgiei a suferit o serie haotică de schimbări și restructurări, cu conceptul său holistic de apărare teritorială (comparabil cu cel din Suedia, Finlanda și țările baltice), încă în primele etape ale implementării. Deoarece armata sovietică nu a fost niciodată organizată pentru apărarea teritorială, țările estice nu au moștenit nicio tradiție de gândire în acest domeniu.

Nuînultimul rând, UE se confruntă cu provocări legate de securitatea energetică a țărilor din estul Europei. Într-o lume ideală, tranzitul energetic ar permite o cooperare constructivă între Rusia, Vest și statele est-europene: Rusia depinde de facilităţi ieftine și sigure pentru exporturile către Europa, Europa are nevoie de surse fiabile de energie (atât de petrol, cât și de gaz) iar statele est-europene doresc să câștige taxe de tranzit, conectându-le pe cele două. Dar, din cauza crizei de tranzit a gazelor prin Ucraina, care a izbucnit în 2006 și 2009, precum și a temerilor că dependența ridicată a unor state membre de gazul, petrolul și electricitatea din Rusia le face vulnerabile la șantaj, UE a început să pună în aplicare o politică energetică comună. În general, politica este concepută pentru a crea o piață internă transparentă, interconectată și competitivă a energiei, care să rupă monopolurile anumitor companii energetice și să diversifice aprovizionarea. Cadrul legal al acestei politici energetice s-a transformat în politică externă, intrucât statele vecine se pot alătura comunității energetice a UE prin adaptarea regulilor și structurii de guvernare la piețele lor energetice. Includerea pe o piață mai largă a UE ar trebui să scadă costul energiei pentru țările est-europene (dintre care unele trebuie să plătească, în prezent, printre cele mai mari prețuri pentru gazul natural din Europa) și ar trebui să își întărească semnificativ eforturile în negocierile privind achizițiile de energie.

S-au înregistrat unele progrese în acest domeniu: Georgia este acum mult mai bine conectată cu țările vecine și și-a diversificat oferta, Ucraina a implementat reforme dureroase la piața internă a energiei și la reglementările de stabilire a prețurilor, rupând, în același timp, monopolurile și eliminând schemele de corupție care s-au dovedit a fi o responsabilitate politică majoră. Totuși, încercările Moldovei de a se conecta cu piaţa românească a gazelor au fost întrerupte atunci când un guvern prorus a venit la putere în noiembrie 2019.

$\mathrm{Cu}$ toate acestea, în următorii ani, problema mai mare privind transportul energiei va consta în faptul dacă țările est-europene vor juca vreun rol în transferul de energie sau dacă Rusia va putea ocoli regiunea în ansamblu prin completarea rețelelor de conducte TurkStream și Nord Stream 2. Țările din estul Europei se tem că, dacă nu ar mai avea nevoie de alte state postsovietice (în special Belarus și Ucraina) pentru tranzitul energetic, Rusia va fi eliberată de o constrângere majoră în încercările sale de a-i intimida, inclusiv prin utilizarea forței militare. Anul trecut, Rusia și Ucraina au evitat o confruntare cu privire la rolul acesteia din urmă în tranzitul de gaze, numai în ultimul moment, ajungând la un acord care va dura până în 2024 
și care stabilește un nivel minim de tranzit anual de gaz pentru a menține infrastructura energetică în Ucraina.

În timp ce UE a intermediat negocierile, în calitate de broker, SUA au fost adevăratul facilitator al acordului. În așteptarea sancțiunilor SUA asupra noilor conducte de gaz rusești (care vizează, în principal, Nord Stream 2, dar care pot complica și întreținerea TurkStream), a fost riscant ca Rusia să ocolească în totalitate estul Europei. Având în vedere că a existat un consens din ce în ce mai mare la Washington cu privire la necesitatea acestor sancțiuni și că Germania a beneficiat de un sprijin redus în cadrul UE pentru Nord Stream 2, președintele rus Vladimir Putin a trebuit să se protejeze împotriva posibilelor evoluții viitoare. Menținerea unui rol minim de tranzit al gazelor pentru Ucraina a făcut parte din acest proces de acoperire. Prin urmare, Rusia și-a amânat decizia finală cu privire la problema tranzitului, iar disputa va continua, probabil, o perioadă de timp.

\section{Concluzii}

Nu este o sarcină ușoară schimbarea blocajului prin sprijin reciproc pe probleme strategice la nivelul țărilor est-europene. $\mathrm{Cu}$ toate acestea, statele membre pot începe să realizeze acest lucru, recunoscând că unii dintre ei au experiență și expertiză specială în relațiile cu diferiți parteneri din UE. Statele membre ale Europei de Est ar trebui să aibă, în general, încredere în Franța, Italia și Spania în problemele care implică Mediterana, Iranul sau procesul de pace din Orientul Mijlociu, iar Franța, Italia și Spania ar trebui să acorde atenție țărilor est-europene în anticiparea mișcărilor și intereselor rusești, precum și în relațiile cu țările est-europene. Statele est-europene ar trebui să se consulte, în prealabil, cu Bruxelles-ul cu privire la mișcările şi politicile planificate, legate de suveranitatea strategică, pentru a le scuti de surprize neplăcute.

Statele membre trebuie să-și extindă portofoliul în domenii cheie, aşa cum au făcut-o de-a lungul istoriei. Franța și alte țări mediteraneene ar trebui să fie de acord să sporească resursele și operațiunile UE în țările est-europene; în schimb, acestea ar trebui să aducă o contribuție mai mare la misiunile franceze din Africa, la operaţiunile de securitate maritimă din Mediterana și la alte iniţiative. Ar trebui să încadreze toate acestea ca o apărare a statu-quoului juridic al ordinului european de securitate.
Rolul Comisiei Europene ar trebui consolidat pentru a evita litigiile bilaterale prelungite dintre statele membre ale UE. De exemplu, dacă Germania ar fi permis Comisiei Europene să își asume responsabilitatea pentru negocierea și lansarea de noi proiecte de conducte, alte state membre ar putea fi acum mai dispuse să ajute astfel de iniţiative să reziste presiunilor externe.

\section{NOTE:}

1 [Consiliul European, Consiliul UE], Cooperarea Uniunii Europene în materie de securitate și apărare, 2020, https://www.consilium.europa.eu/ro/policies/defencesecurity/, accesat la 14.10.2021.

2 https://library.fes.de/pdf-files/bueros/bukarest/12413. pdf, accesat la 19.10.2021.

\section{Ibidem.}

$4 \mathrm{https}: / /$ books.google.ro/books?id=19T_IH6ZdiEC\&p $\mathrm{g}=\mathrm{PA} 54 \& \mathrm{lpg}=\mathrm{PA} 54 \& \mathrm{dq}=$ rusia + deflector + strategic \&source $=$ bl\&ots $=$ jUH3wlpl1 $\&$ sig $=A C f U 3 U 1 \mathrm{bmmf05lzeymG76D}$ 74SJxSNFKQ1Q\&hl =ro\&sa $=X \& v e d=2$ ahUKEwjK1rbej_n zAhUOsaQKHcHRAHsQ6AF6BAgWEAM\#v=onepage $\& q=$ rusia $\% 20$ deflector $\% 20$ strategic $\& f=$ false, accesat la 19.10.2021.

\section{BIBLIOGRAFIE}

[Cologne European Council], Conclusions of The Presidency, June 3-4,1999, https://www. europarl.europa.eu/summits/kol2_en.htm\#an3

[Comisia Europeană], Un fond european de apărare: 5,5 miliarde EUR pe an pentru stimularea capacităților de apărare ale Europei, 2017, https:// ec.europa.eu/commission/ presscorner/ detail/ro/ IP_17_1508

[ConsiliulEuropean, ConsiliulUE], Cooperarea Uniunii Europene în materie de securitate și apărare, 2020, https://www.consilium.europa.eu/ ro/policies/defence-security/

[Consiliul European, Consiliul UE], Concluzii Reuniunea Consiliului European, 28 iunie 2018, https://www.consilium.europa.eu/media/359 54/28-euco-final-conclusions-ro.pdf

[Consiliul European, Consiliul UE], Joint UENATO Declarațion, Bruxelles, 2018, https://www. consilium.europa.eu/media/36096/nato_eu_final_ eng.pdf

[Consiliul European], Fifth progress report on the implementation of the common set of proposals endorsed by EU and NATO Councils on 6 December 2016 and 5 December 2017, https:// www.consilium.europa.eu/media/44451/200616progress-report-nr5-eu-nato-eng.pdf 
[Consiliul European, Consiliul UE], Cooperarea la nivelul UE în domeniul apărării, 2017, https://www.consilium.europa.eu/ro/ press/press-releases/2017/06/08/military-mpccplanning-conduct-capability

[Consiliul European, Consiliul UE], Politica de Securitate și Apărare Comună Civilă, 2018, https://www.consilium.europa.eu/ro/press/pressreleases/2018/11/19/civilian-common-securityand-defence-policy-eu-strengthens-its-capacitiesto-act/

[Consiliul European, Consiliul UE], Taking EU-NATO cooperation to a new level, 2016, https://www.consilium.europa.eu/en/press/pressreleases/2016/12/13/tusk-juncker-stoltenbergopinion/

[EEAS], A Global Strategy for the Europeen Union's Foreign and Security Policy, 2016.

[European Defence Agency], Mission, https:// www.eda.europa.eu/Aboutus/Missionandfunctions

Dr. Bădălan E.,\& dr. Frunzeti T., Forțe și tendințe în mediul de securitate european, Editura Academiei Forțelor Terestre „Nicolae Bălcescu”, Sibiu, 2003.

Bogzeanu C., Evoluția relației NATO-UE față de determinarea polilor de putere, Editura Universității Naţionale de Apărare „Carol I”, București, 2013.

Dr.DuțuP.,BogzeanuC., Reformainstituțională a UE din perspectiva Politicii de Securitate și
Apărare Comune, Editura Universității Naționale de Apărare „Carol I”, București, 2011.

Horoșanu G., NATO-UE a smarter collaboration, Editura Tritonic, București, 2014.

Mureșan M., Țenu C., Stăncilă L., Securitatea europeană la inceputul mileniului 3, Editura Universității Naționale de Apărare „Carol I", București, 2006.

Dr. Pavel Gh., Mediul de securitate european și euroatlantic, Editura Universitătii Naționale de Apărare „Carol I”, București, 2007.

Stoica A1., Marii actori statali și Uniunea Europeană în competiția globală de interese, Editura Universității Naționale de Apărare „Carol I”, București, 2014.

https://ec.europa.eu/info/strategy/priorities2019-2024/promoting-our-european-way-life/ european-security-union_ro;

https://www.consilium.europa.eu/ro/press/ press-releases/2021/05/10/security-and-defenceeu-to-move-forward-on-common-security-anddefence/;

https://books.google.ro/books?id=19T IH6Z diEC\&pg $=$ PA54\&lpg $=$ PA54\&dq $=$ rusia + deflector + strategic \& source $=$ bl\&ots $=\mathrm{jUH} 3$ wlpl1 $\mathrm{m} \& \operatorname{sig}=\mathrm{A}$ CfU3U1bmmf05lzeymG76D74SJxSNFKQ1Q\&h $1=$ ro\&sa=X\&ved=2ahUKEwjK1rbej_nzAhUOsa QKHcHRAHsQ6AF6BAgWEAM\#v=onepage\&q $=$ rusia $\% 20$ deflector $\% 20$ strategic $\& \mathrm{f}=$ false.

https://library.fes.de/pdf-files/bueros/buka rest/12413.pdf 